\title{
Intracellular Chloride Ions Regulate the Time Course of GABA-Mediated Inhibitory Synaptic Transmission
}

\author{
Catriona M. Houston, Damian P. Bright, Lucia G. Sivilotti, Marco Beato, ${ }^{\star}$ and Trevor G. Smart* \\ Department of Neuroscience, Physiology \& Pharmacology, University College London, London WC1E 6BT, United Kingdom
}

The time-dependent integration of excitatory and inhibitory synaptic currents is an important process for shaping the input-output profiles of individual excitable cells, and therefore the activity of neuronal networks. Here, we show that the decay time course of GABAergic inhibitory synaptic currents is considerably faster when recorded with physiological internal $\mathrm{Cl}^{-}$concentrations than with symmetrical $\mathrm{Cl}^{-}$solutions. This effect of intracellular $\mathrm{Cl}^{-}$is due to a direct modulation of the $\mathrm{GABA}_{\mathrm{A}}$ receptor that is independent of the net direction of current flow through the ion channel. As a consequence, the time window during which GABAergic inhibition can counteract coincident excitatory inputs is much shorter, under physiological conditions, than that previously measured using high internal $\mathrm{Cl}^{-}$. This is expected to have implications for neuronal network excitability and neurodevelopment, and for our understanding of pathological conditions, such as epilepsy and chronic pain, where intracellular $\mathrm{Cl}^{-}$concentrations can be altered.

\section{Introduction}

The time course of synaptic $\mathrm{GABA}_{\mathrm{A}}$ receptor-mediated IPSC will profoundly influence the excitability of individual neurons and networks, by setting the duration of a time window during which an inhibitory input can most effectively counteract a coincident excitatory input.

The IPSC time course is determined by both presynaptic and postsynaptic factors at inhibitory synapses. These include the concentration-time profile of GABA in the synaptic cleft, which is itself affected by the density of GABA transporters and the degree of synchrony for presynaptic GABA release (Overstreet and Westbrook, 2003; Hefft and Jonas, 2005; Keros and Hablitz, 2005), as well as several postsynaptic factors, such as the following: the presence of perisynaptic $\mathrm{GABA}_{\mathrm{A}}$ receptors, which prolong the IPSC decay phase (Wei et al., 2003), the subunit composition of synaptic receptors (Barberis et al., 2007), and the phosphorylation state of $\mathrm{GABA}_{\mathrm{A}}$ receptor subunits (Jones and Westbrook, 1997; Houston et al., 2008). Another factor, which has received less consideration and may also influence IPSC decays, is the nature and concentration of permeant ions through the ligandgated ion channel. These are known to affect the kinetics of voltage-gated ion channels (Stanfield et al., 1981; Swenson and Armstrong, 1981), but there are very few reports of such an effect on synaptic ligand-gated channels (Marchais and Marty, 1979; Onodera and Takeuchi, 1979; Schneggenburger and Ascher,

Received April 7, 2009; revised June 2, 2009; accepted June 5, 2009.

This work was supported by the Medical Research Council (UK) to T.G.S. and L.G.S., and by a Royal Society University Research Fellowship and Wellcome Trust support to M.B. We thank Angus Silver and Jason Rothman for the loan of the dynamic clamp amplifier. After completion of our study, we learned that unpublished observations similar to those described in the present paper were independently made by Joel Charvas, Christophe Pouzat, and Alain Marty.

${ }^{*} M$.B. and T.G.S. contributed equally to this work.

Correspondence should be addressed to Prof. Trevor G. Smart, Department of Neuroscience, Physiology \& Pharmacology, University College London, London WC1E 6BT, UK. E-mail: t.smart@ucl.ac.uk.

DOI:10.1523/JNEUROSCI.1670-09.2009

Copyright $\odot 2009$ Society for Neuroscience ～0270-6474/09/2910416-08\$15.00/0
1997). Indeed, for $\mathrm{GABA}$ ion channels, such a modulation by $\mathrm{Cl}^{-}$ would not have been readily observed before, as most patchclamp studies of synaptic inhibition routinely use matching high internal and external $\mathrm{Cl}^{-}$concentrations to set the $\mathrm{Cl}^{-}$reversal potential near to zero. This is convenient because it increases the amplitude of the IPSC at the negative holding potentials that are suitable for whole-cell recording.

Here, we report that intracellular $\mathrm{Cl}^{-}$, by acting directly on the $\mathrm{GABA}_{\mathrm{A}}$ receptor, critically affects the GABAergic IPSC decay phase at interneuron-Purkinje cell inhibitory synapses in the cerebellum. At low $\mathrm{Cl}^{-}$concentrations, typically approaching those found in neurons $(\sim 5-10 \mathrm{~mm})$, the IPSC decay phase is rapid, and the duration of the IPSC shorter. We found that by incrementally raising the internal $\mathrm{Cl}^{-}$concentration, the IPSC decay time was proportionately increased. Thus, variations of the intracellular $\mathrm{Cl}^{-}$concentration, following physiological or pathophysiological processes, will have a crucial impact on the IPSC profile with important implications for the dynamics of inhibitory transmission throughout the CNS.

\section{Materials and Methods}

Preparation of slices. Thin sagittal slices $(250 \mu \mathrm{m})$ were cut from the cerebellum of postnatal day 12 Sprague Dawley rats using a Leica VT1200s vibroslicer, in accordance with the UK Animals (Scientific Procedures) Act of 1986. Slices were cut in an artificial CSF (aCSF) solution containing (in mM) $125 \mathrm{NaCl}$ (or $85 \mathrm{NaCl}, 75$ sucrose), 2.5 $\mathrm{KCl}, 1.25 \mathrm{NaH}_{2} \mathrm{PO}_{4}, 26 \mathrm{NaHCO}_{3}, 1 \mathrm{CaCl}_{2}, 5 \mathrm{MgCl}_{2}$, and 11 glucose, gassed with $95 \% \mathrm{O}_{2} / 5 \% \mathrm{CO}_{2}$ at $4^{\circ} \mathrm{C}$. The slices were then incubated at $35^{\circ} \mathrm{C}$ for $45 \mathrm{~min}$ before being allowed to cool to room temperature $\left(23^{\circ} \mathrm{C}\right)$ before use. Over this time the solution was slowly changed to standard aCSF and slices were perfused in the recording bath at room temperature containing (in $\mathrm{mm}$ ) $125 \mathrm{NaCl}, 2.5 \mathrm{KCl}, 1.25 \mathrm{NaH}_{2} \mathrm{PO}_{4}$, $26 \mathrm{NaHCO}_{3}, 2 \mathrm{CaCl}_{2}, 2 \mathrm{MgCl}_{2}$, and 11 glucose, gassed with $95 \%$ $\mathrm{O}_{2} / 5 \% \mathrm{CO}_{2}$ (Duguid and Smart, 2004; Bright et al., 2007). For the bicarbonate-free experiments, the ACSF contained (in $\mathrm{mM}$ ) $135 \mathrm{NaCl}$, $2.5 \mathrm{KCl}, 1.25 \mathrm{NaH}_{2} \mathrm{PO}_{4}, 20 \mathrm{HEPES}, 2 \mathrm{CaCl}_{2}, 2 \mathrm{MgCl}_{2}$, and 11 glucose (Kaila et al., 1997), gassed with $100 \% \mathrm{O}_{2}$. To block NMDA and AMPA 


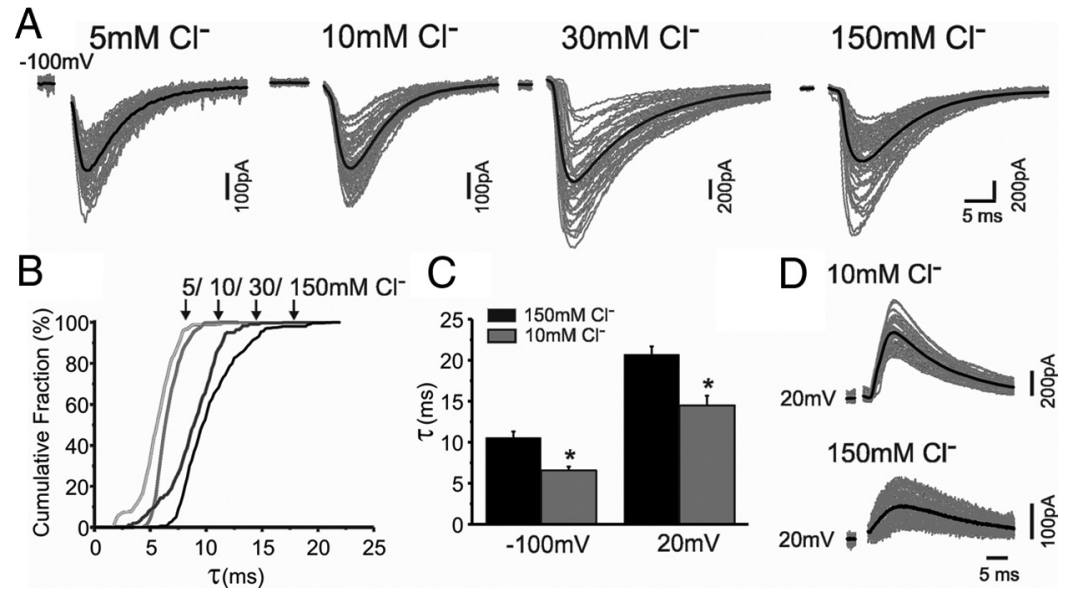

Figure 1. Reducing intracellular $\mathrm{Cl}^{-}$concentration decreases the decay time constant of evoked IPSCS. $A$, Consecutively evoked (gray) and averaged (black) elPSCs recorded at $-100 \mathrm{mV}$ from Purkinje cells in an acute cerebellar slice using:5, 10, 30, or $150 \mathrm{~mm}$ internal $\mathrm{Cl}^{-}$solutions. $\boldsymbol{B}$, Cumulative distributions for elPSC decay times measured at $-100 \mathrm{mV}$ in Purkinje cells recorded with 5 , 10,30 , or $150 \mathrm{~mm}$ internal $\mathrm{Cl}^{-}$. C, Bar chart of the decay-time constants for elPSCs at $-100(n=13)$ and $20 \mathrm{mV}(n=6)$ holding potentials with high (black, $150 \mathrm{~mm}$ ) or low (gray, $10 \mathrm{~mm}$ ) internal $\mathrm{Cl}^{-}$concentrations (means $\pm \mathrm{SEM},{ }^{*} p<0.05$ ). $\boldsymbol{D}$, Consecutive (gray) and averaged (black) elPSCs, recorded with either a 10 or $150 \mathrm{~mm}$ internal $\mathrm{Cl}^{-}$solutions at $20 \mathrm{mV}$.

receptor activation, $20 \mu \mathrm{M} \mathrm{AP}-5$ and $10 \mu \mathrm{M}$ CNQX were added to the standard aCSF.

Expression of recombinant receptors in HEK293 cells and fast concentration jumps. HEK293 cells were transfected $6 \mathrm{~h}$ after plating using the calcium phosphate precipitation method with $4 \mu \mathrm{g}$ of DNA of $\alpha \beta \gamma \mathrm{GABA}_{\mathrm{A}}$ receptor subunits and EGFP in equimolar ratios per $35 \mathrm{~mm}$ dish. Cells were bathed in a solution composed of (in $\mathrm{mm}$ ) $102.7 \mathrm{NaCl}, 20 \mathrm{Na}$ gluconate, $2 \mathrm{KCl}, 2 \mathrm{CaCl}_{2}, 1.2 \mathrm{MgCl}_{2}, 10 \mathrm{HEPES}, 14$ glucose, 15 sucrose, and 20 TEA-Cl, pH adjusted to 7.4 with $\mathrm{NaOH}$ (osmolarity $\sim 320 \mathrm{mOsm}$ ). Recordings were obtained in the outside-out patch configuration using either a high- $\mathrm{Cl}^{-}$pipette solution $\left(107.1 \mathrm{KCl}, 1 \mathrm{CaCl}_{2}, 1 \mathrm{MgCl}_{2}, 10\right.$ HEPES, 11 EGTA, 20 TEA-Cl, and $2 \mathrm{MgATP}$ ) or a low-Cl ${ }^{-}$solution (121.1 K gluconate, $1 \mathrm{CaCl}_{2}, 1 \mathrm{MgCl}_{2}, 10 \mathrm{HEPES}, 11 \mathrm{EGTA}, 6 \mathrm{TEA}-\mathrm{Cl}$, and $2 \mathrm{MgATP}$ ). Concentration jumps were performed using a theta tube (outer diameter $2 \mathrm{~mm}$, inner diameter 1.7, septum 0.117, 14-072-01, Hilgenberg) whose tip was cut with a diamond pen to a final diameter of $\sim 150 \mu \mathrm{m}$. The theta tubes were filled with control solution, and $3 \mathrm{~mm}$ GABA was added to one of the two barrels. Fast drug applications were performed by delivering a short (1-2 ms) voltage pulse to a piezo-stepper (Burleigh Instruments). The exchange time was measured by applying a $20 \%$ diluted solution to the open tip of the recording pipette after rupture of the patch and measuring the resulting junction potentials. Experiments were included in the analysis if the exchange time was faster than $150 \mu$ s. A minimum of 10 individual responses at five different voltages (from -100 to $+60 \mathrm{mV}$ in $40 \mathrm{mV}$ steps) were averaged and fitted with a mixture of two or three exponentials. Weighted time constants are reported throughout the text.

Electrophysiology. Whole-cell patch-clamp recordings were made from single cells identified by differential interference contrast microscopy (Nikon Eclipse E 600FN) using a MultiClamp 700A amplifier in the voltage-clamp configuration (Molecular Devices). Patch pipettes (1.5-2 $\mathrm{M} \Omega$ ) were filled with solutions containing the following (in $\mathrm{mm}): 140 \mathrm{CsCl}\left(150 \mathrm{~mm} \mathrm{Cl}^{-}\right), 140 \mathrm{Cs}$-gluconate $\left(10 \mathrm{~mm} \mathrm{Cl}^{-}\right)$, or 20 $\mathrm{CsCl}$ and $120 \mathrm{Cs}$-gluconate $\left(30 \mathrm{~mm} \mathrm{Cl}^{-}\right)$; and $4 \mathrm{NaCl}, 0.5 \mathrm{CaCl}_{2}, 5$ EGTA, 10 HEPES, $2 \mathrm{Mg}_{2} \mathrm{ATP}$, and 5 QX-314-Cl, pH adjusted to 7.3 with $\mathrm{CsOH}$. The osmolarity was adjusted to $310 \mathrm{mOsm}$ with sucrose. To make a $5 \mathrm{mM} \mathrm{Cl}^{-}$internal solution, $4 \mathrm{NaCl}$ was replaced with 4 Na-gluconate and 4 QX-314-Cl.

Currents were filtered at $3 \mathrm{kHz}$ (Bessel filter), digitized at $20 \mathrm{kHz}$ and analyzed using Clampex 8.2 (Molecular Devices). Series resistance after compensation was typically between 2 and $3 \mathrm{M} \Omega(<1 \mathrm{M} \Omega$ for experiments at $\left.37^{\circ} \mathrm{C}\right)$ and was constantly monitored throughout recording. Cells were not used for analysis if their series resistance changed by $>10-$ $15 \%$. The capacitance of a typical Purkinje cell at this age was $355 \pm 37 \mathrm{pA}$
( $n=7$ ), and cells that deviated from this by $>20 \%$ were not used for analysis. Cells were continuously superfused with CNQX $(10 \mu \mathrm{M})$ and AP-5 $(20 \mu \mathrm{M})$ to block glutamatemediated fast synaptic transmission.

The stimulating electrode was a patch electrode filled with aCSF positioned within the lower third of the molecular layer, $\sim 150 \mu \mathrm{m}$ lateral to the Purkinje cell body (Mittmann and Hausser, 2007) to preferentially stimulate basket cells that form a GABAergic synapse close to the soma at the axon initial segment (Ango et al., 2004). Stimulation was applied through a constant current stimulator (DS3, Digitimer) and gradually increased until an evoked IPSC (eIPSC) could be detected in the recorded Purkinje cell. This stimulation was increased until the amplitude of the eIPSC increased substantially presumably due to recruitment of more basket cells. The stimulation intensity was then set at $\sim 1.5$ times the threshold, and only cells where there was a clear separation between the stimulation transient and the rising phase of the eIPSC were used.

Data analysis. The decay times of IPSCs were determined in Clampfit 8.2 by fitting a single exponential to the $(90-$ $10 \%)$ decay phase. At each holding potential, individual IPSCs were examined and those with any deflection in the rising or decaying phases were deleted, as were any failures, before fitting the mean IPSC. Averaged IPSCs included $\sim 30-50$ individual sweeps. In cumulative distribution plots the individual decay times of each IPSC were plotted and normalized between cells. Spontaneous (s)IPSCs were analyzed using MiniAnalysis (version 6.0.1, Synaptosoft) and were also fitted with a single exponential (Houston et al., 2008). IPSC events were selected for analysis if there were no deflections in their rising or decaying phases and they decayed back to the baseline holding current. Events of low amplitude $(<10 \mathrm{pA})$ and slow rise times $(10-90 \%>3 \mathrm{~ms})$ were discarded from this analysis as they were thought to represent events occurring at more distant synapses and therefore more likely to be affected by dendritic cabling (Llano et al., 2000).

Dynamic clamp experiments. Current-clamp recordings from Purkinje neurons used a standard intracellular solution composed of (in $\mathrm{mM}$ ) 130 $\mathrm{KCl}, 10 \mathrm{HEPES}, 1 \mathrm{CaCl}_{2}, 4 \mathrm{NaCl}, 5 \mathrm{EGTA}$, and $4 \mathrm{MgATP}$, pH 7.3 with $\mathrm{KOH}$. A GABAergic conductance was simulated with a function of the following form:

$$
y=A \cdot\left(1-e^{-\frac{t-t_{0}}{\tau_{\text {rise }}}}\right) \cdot\left(e^{-\frac{t-t_{0}}{\tau_{\text {decay }}}}\right)
$$

where $t_{0}$ represents the start of the waveform, $\tau_{\text {rise }}$ was $1.8 \mathrm{~ms}$ (determined from our eIPSC recordings), and $\tau_{\text {decay }}$ was either $8.5 \mathrm{~ms}$ (simulating low $\mathrm{Cl}^{-}$conditions) or $12.5 \mathrm{~ms}$ (replicating our decays in high $\mathrm{Cl}^{-}$at $-60 \mathrm{mV}$, data not shown). This waveform was injected through a dynamic clamp amplifier (SM-1, Cambridge Conductance) setting the reversal potential to $-85 \mathrm{mV}$ (Chavas and Marty, 2003) and a conductance of $15 \mathrm{nS}$. Trains of spikes were evoked by constant current injection and superimposed with either a fast or a slow conductance. Excitatory (AMPA-like) conductances had the same functional profile as those used for simulating inhibition, but with a rise time of $0.3 \mathrm{~ms}$ and a decay time of $3 \mathrm{~ms}$. The value of the conductance was adjusted to be $10-20 \%$ above the threshold for firing (typically 12-18 nS). The inhibitory conductance (either fast or slow) was injected with a variable latency within a $120 \mathrm{~ms}$ window and repeated at $4 \mathrm{~ms}$ intervals.

Statistics. For the statistical comparison of two means, an unpaired, two-tailed Student's $t$ test was used, or the nonparametric alternative, Mann-Whitney test, if there was a significant difference in the group SD as determined by an $F$ test. With all statistical tests, two means were 
considered significantly different if $p<0.05$. Statistical tests were performed using GraphPad Instat version 3.01.

\section{Results}

Evoked, spontaneous, and miniature IPSC decay times are affected by internal $\mathrm{Cl}^{-}$concentration

To determine whether the intracellular $\mathrm{Cl}^{-}$concentration affects the kinetics of IPSCs, we recorded evoked and spontaneous IPSCs in cerebellar Purkinje cells, which receive inhibitory afferents from basket and stellate cells in the molecular layer. We used several different internal $\mathrm{Cl}^{-}$concentrations, from the high symmetrical $\mathrm{Cl}^{-}$frequently used in most electrophysiological experiments, to the low intracellular $\mathrm{Cl}^{-}$normally found in mature Purkinje neurons (Chavas and Marty, 2003); IPSCs were evoked by applying focal stimulation from a patch pipette filled with aCSF positioned in the lower third of the molecular layer. At a holding potential of $-100 \mathrm{mV}$, the eIPSC decay was fit with a single exponential (Fig. 1A) (Puia et al., 1994), with a time constant, $\tau$, that visibly increased with the internal $\mathrm{Cl}^{-}$concentration (Fig. $1 A, C$ ). This consistent change in the decay times with the internal $\mathrm{Cl}^{-}$concentrations was clearly evident from the lateral shifts in the cumulative distribution for IPSC decay time constants (Fig. $1 B$ ). By reducing internal $\mathrm{Cl}^{-}$from 150 to $10 \mathrm{~mm}$, the median $\tau$ was reduced from 10.2 to $6.5 \mathrm{~ms}$ at -100 $\mathrm{mV}$ (150 mM: mean $\tau=10 \pm 0.5 \mathrm{~ms} ; 10$ $\mathrm{mM}: \tau=6.6 \pm 0.2 \mathrm{~ms}, p=0.0001$, MannWhitney test, $n=13$ ), and from 20.5 to 14 $\mathrm{ms}$ at $20 \mathrm{mV}$ (150 mM: mean $\tau=20.7 \pm$ $1.0 \mathrm{~ms} ; 10 \mathrm{~mm}: \tau=14.5 \pm 1.2 \mathrm{~ms}, p=$ 0.004, Mann-Whitney test, $n=6$ ) (Fig. 1C). At $-100 \mathrm{mV}$, increasing internal $\mathrm{Cl}^{-}$ over a physiologically relevant range from 5 to $30 \mathrm{~mm}$, caused $\tau$ to increase by $\sim 59 \%$.

By comparing the eIPSC decay time constants at different holding potentials, it was apparent that the IPSC decays were also voltage dependent (Fig. 1C,D) [cf. Collingridge et al. (1984) and Otis and Mody (1992)]. The ratio of $\tau$ at $+20 \mathrm{mV}$ and $-100 \mathrm{mV}\left(\tau_{20} / \tau_{100}\right)$ was $2.10 \pm 0.19$ with symmetrical $\mathrm{Cl}^{-}$(mean $\left.\pm \mathrm{SEM} ; n=6\right)$ and $2.35 \pm 0.04(n=5)$ with low internal $\mathrm{Cl}^{-}$, suggesting that the voltage dependence of the IPSC decay was unaltered by the $\mathrm{Cl}^{-}$concentration. In marked contrast, at $-100 \mathrm{mV}, \tau$ was consistently reduced by lowering the internal $\mathrm{Cl}^{-}$concentration [-100 mV: $9.7 \mathrm{~ms}\left(150 \mathrm{mM} \mathrm{Cl}^{-}\right), 8.9 \mathrm{~ms}(30 \mathrm{~mm}), 6.3 \mathrm{~ms}(10 \mathrm{~mm}$ $\left.\left.\mathrm{Cl}^{-}\right), 5.6 \mathrm{~ms}(5 \mathrm{~mm})\right]$, a feature also noted at $20 \mathrm{mV}$ [20.4 $\mathrm{ms}(150$ $\mathrm{mM}), 13.9 \mathrm{~ms}(10 \mathrm{~mm}) ; n=5-6]$. Given that internal $\mathrm{Cl}^{-}$affected the speed of the eIPSC decay at -100 and $20 \mathrm{mV}$ to a similar extent, it is clear that this regulation must be independent of the net direction of current flow (Fig. 1D).

We also examined whether the internal $\mathrm{Cl}^{-}$concentration similarly affected spontaneous IPSCs (sIPSCs). In accord with the
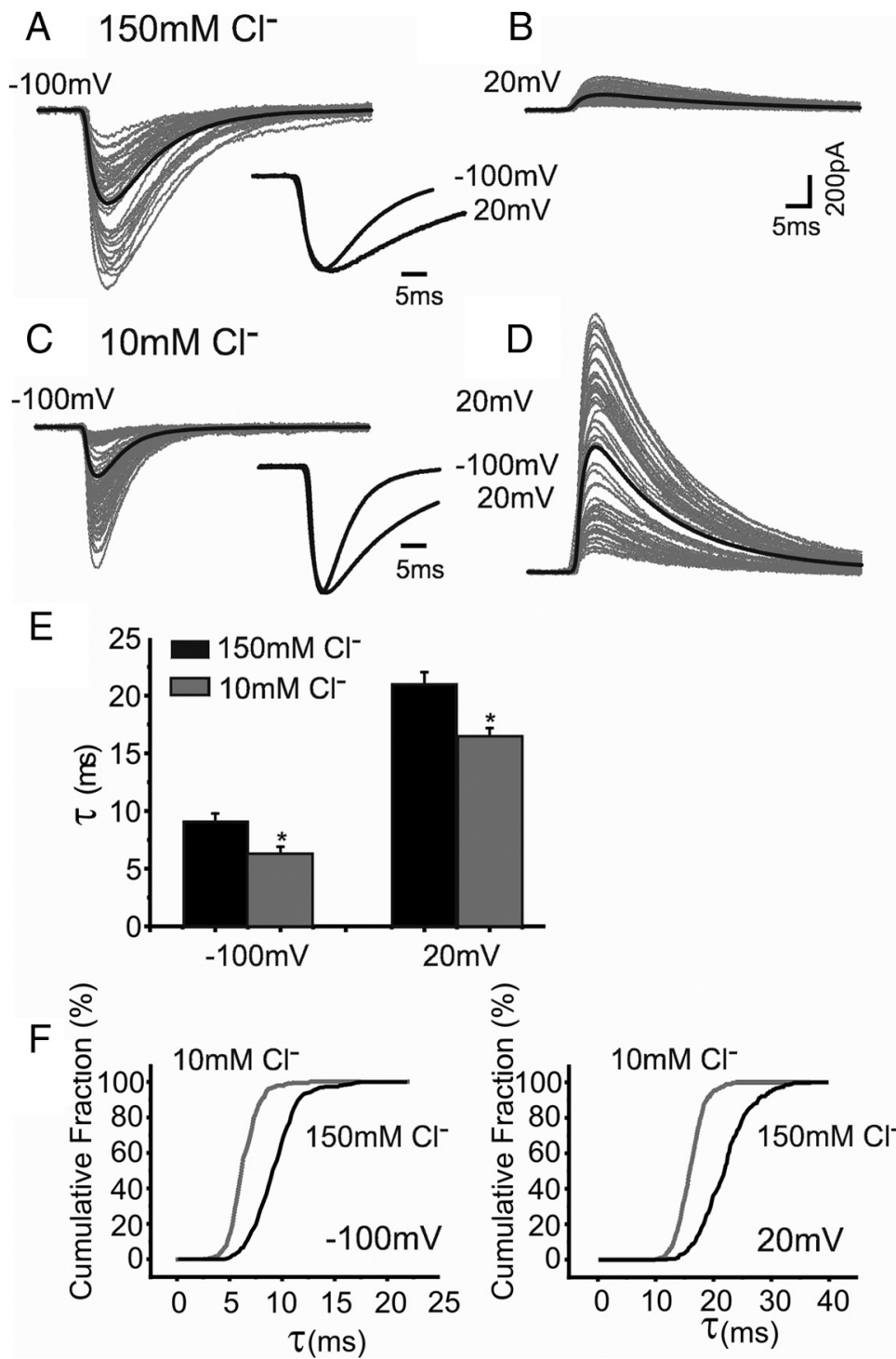

Figure 2. Intracellular $\mathrm{Cl}^{-}$regulates the decay phase of spontaneous IPSCs. A, sIPSCs (gray) and averaged sIPSC (black) recorded from Purkinje cells with $150 \mathrm{~mm} \mathrm{Cl}^{-}$internal solution at $-100 \mathrm{mV}$. The averaged and peak-scaled sIPSCs recorded at -100 and $20 \mathrm{mV}$ (sIPSCs are inverted) are overlaid (inset). $\boldsymbol{B}$, The same protocol as in $\boldsymbol{A}$ for individual and averaged sIPSCs recorded -100 and $20 \mathrm{mV}$ are overlaid (inset). D, sIPSCs clamped at $20 \mathrm{mV}\left(10 \mathrm{~mm} \mathrm{Cl}{ }^{-}\right)$. The scale bar in $\boldsymbol{B}$ applies to all. $\boldsymbol{E}$, Bar chart of mean sIPSC decay-time constants at different holding potentials with high (black) or low (gray) internal $\mathrm{Cl}^{-}$. $\boldsymbol{F}_{\text {, Cumulative probability }}$ plots for sIPSC decay times at $-100 \mathrm{mV}$ and $+20 \mathrm{mV}$ with high (black) and low (gray) $\mathrm{Cl}^{-}$.

eIPSC data, the decay profiles of sIPSCs were described by single exponentials and displayed a similar voltage sensitivity from $-100 \mathrm{mV}$ to $+20 \mathrm{mV}$, with $\tau$ increasing with membrane depolarization (Fig. 2A-D). Recording from Purkinje cells with $150 \mathrm{~mm}$ internal $\mathrm{Cl}^{-}$concentrations the $\tau_{20} / \tau_{100}$ ratio was $\sim 2.33 \pm 0.14$ $(n=6)$ (Fig. $2 E$ ), and remained constant at $10 \mathrm{mM} \mathrm{Cl}^{-}$concentration (2.64 $\pm 0.13, n=6$ ) (Fig. $2 E$ ). As observed from experiments with eIPSCs, a low internal $\mathrm{Cl}^{-}$concentration $(10 \mathrm{~mm})$, reduced the mean decay time constant for sIPSCs at all holding potentials examined $[-100 \mathrm{mV}: 9.2 \pm 0.6 \mathrm{~ms}(150$ $\left.\mathrm{mM} \mathrm{Cl}^{-}\right), 6.4 \pm 0.5 \mathrm{~ms}\left(10 \mathrm{mM} \mathrm{Cl}^{-}\right) ; 20 \mathrm{mV}: 21.0 \pm 1.1 \mathrm{~ms}(150$ $\left.\mathrm{mM} \mathrm{Cl}^{-}\right), 16.6 \pm 0.6 \mathrm{~ms}\left(10 \mathrm{mM} \mathrm{Cl}^{-}\right), p=0.009$ at -100 and $20 \mathrm{mV}$, Mann-Whitney test, $n=6$ ] (Fig. 2E). The displacements in the cumulative distributions for sIPSC decay times also revealed a consistent effect of the low $\mathrm{Cl}^{-}$concentration in reducing the median decay time constant $[-100 \mathrm{mV}, 9.1 \mathrm{~ms}(150 \mathrm{~mm}$ 


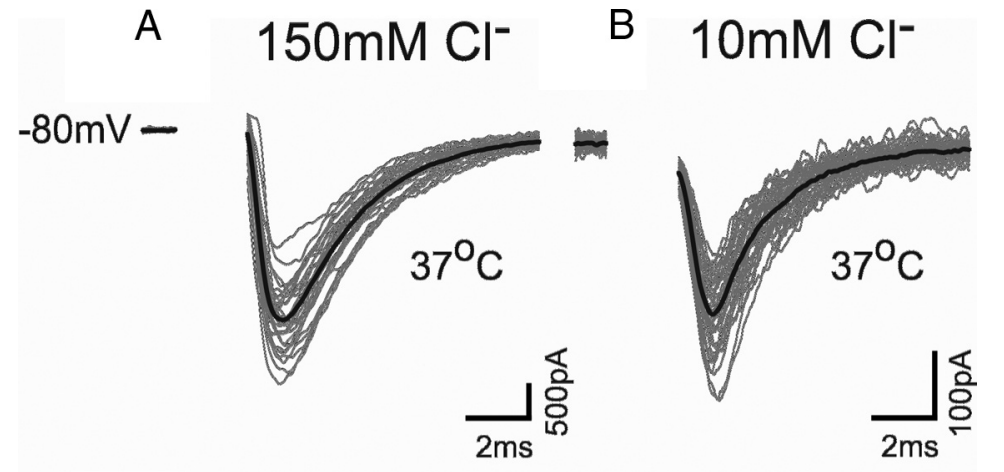

C

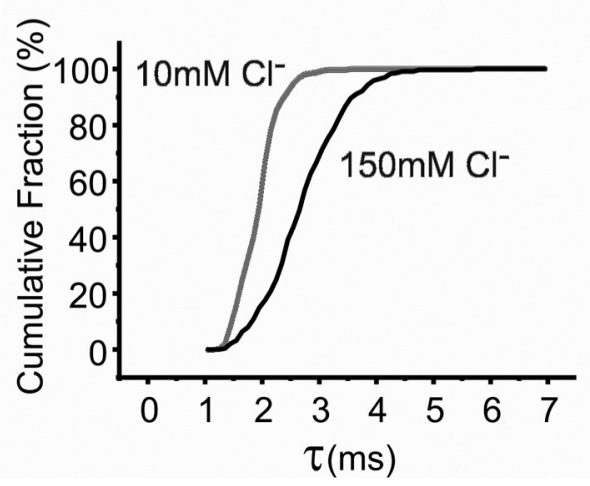

Figure 3. Effect of low internal $\mathrm{Cl}^{-}$on IPSC decays at $37^{\circ} \mathrm{C}$. Consecutively evoked (gray) and averaged elPSCS (black) recorded at $37^{\circ} \mathrm{C}$ from cerebellar Purkinje cells held at $-80 \mathrm{mV}$ with a $150 \mathrm{~mm}(\boldsymbol{A})$ or $10 \mathrm{~mm}(\boldsymbol{B})$ internal $\mathrm{Cl}^{-}$solution. $\boldsymbol{C}$, Cumulative probability relationships for elPSC decay time constants at $-80 \mathrm{mV}$ and $37^{\circ} \mathrm{C}$ with $150 \mathrm{~mm}$ (black) and $10 \mathrm{~mm}$ (gray) internal $\mathrm{Cl}^{-}$ $(n=6-8)$.

$\left.\mathrm{Cl}^{-}\right), 6.2 \mathrm{~ms}\left(10 \mathrm{mM} \mathrm{Cl}^{-}\right) ; 20 \mathrm{mV}: 21.9 \mathrm{~ms}\left(150 \mathrm{mM} \mathrm{Cl}^{-}\right), 15.9$ $\left.\mathrm{ms}\left(10 \mathrm{mM} \mathrm{Cl}^{-}\right) ; n=6\right]$ (Fig. $\left.2 F\right)$.

In accord with our results with eIPSCs and sIPSCs, internal $\mathrm{Cl}^{-}$also regulated the decay times of miniature IPSCs (mIPSCs). By reducing internal $\mathrm{Cl}^{-}$, the mIPSC decay time constant measured at $-100 \mathrm{mV}$ was reduced from $\tau\left(\right.$ high $\left.\mathrm{Cl}^{-}\right)=$ $9.6 \pm 0.8 \mathrm{~ms}$ to $\tau\left(\right.$ low $\left.\mathrm{Cl}^{-}\right)=6.8 \pm 0.4 \mathrm{~ms}(n=6 ; p=0.018)$. Similarly, at a holding potential of $+20 \mathrm{mV}, \tau\left(\right.$ high $\mathrm{Cl}^{-}$) was reduced from $23.1 \pm 0.6 \mathrm{~ms}$ and $\tau$ (low $\mathrm{Cl}^{-}$) to $16.5 \pm 0.7 \mathrm{~ms}$ ( $n=6 ; p=0.0003$; unpaired $t$ test).

The increased decay rate for IPSCs recorded with low internal $\mathrm{Cl}^{-}$is expected to increase further when the recording temperature is raised from $23^{\circ} \mathrm{C}$ to $37^{\circ} \mathrm{C}$. When eIPSCs were recorded at physiological temperatures from Purkinje neurons held at -80 $\mathrm{mV}$, reducing the internal $\mathrm{Cl}^{-}$from 150 to $10 \mathrm{~mm}$ also reduced their median decay time constant from $2.7 \mathrm{~ms}$ to $1.9 \mathrm{~ms}$ ( $p=$ 0.01; Mann-Whitney; $n=6-8$ ) (Fig. $3 A, B$ ). The cumulative distribution for the decay times (Fig. $3 C$ ) indicated that the median $\tau$ for $10 \mathrm{~mm} \mathrm{Cl}^{-}$at $37^{\circ} \mathrm{C}$ approached the limit we can effectively resolve with the level of low-pass filtering imposed by the combination of whole-cell capacitance and series resistance. It is for this reason that most of the subsequent experiments were conducted at room temperature.

\section{IPSC decay times are unaffected by $\mathrm{HCO}_{3}^{-}$permeation through GABA channels}

Although $\mathrm{Cl}^{-}$is the major permeating anion through GABA channels, it is known that $\mathrm{HCO}_{3}^{-}$ions also have an appreciable permeability through synaptic GABA channels in mammalian neurons (Bormann et al., 1987; Kaila et al., 1993), with a $P_{\mathrm{HCO}_{3}}$ I $P_{\mathrm{Cl}}$ ratio of $\sim 0.2$ (Kaila, 1994). Whether the internal $\mathrm{HCO}_{3}^{-}$ concentration was also important for the regulation of the IPSC decay time was examined by comparing eIPSCs recorded from Purkinje neurons bathed in aCSF or in an $\mathrm{O}_{2}$-gassed/HEPES-based external solution to create a nominally $\mathrm{HCO}_{3}^{-}$free solution (Fig. $4 A-D$ ). In the $\mathrm{HCO}_{3}^{-}$free, $10 \mathrm{mM} \mathrm{Cl}^{-}$solution, the amplitudes of the eIPSCs were reduced to $65.8 \pm$ $7.5 \%$ of their value compared in normal aCSF $(p=0.05$, unpaired two-tailed $t$ test, $n=6-8)$.

However, by using an $150 \mathrm{~mm}$ internal $\mathrm{Cl}^{-}$concentration, eIPSC amplitudes remained unaffected by switching to an $\mathrm{HCO}_{3}^{-}$-free aCSF $(95.2 \pm 9.8 \% ; p=0.5$, $n=6-8)$. This reflected the relative contributions of $\mathrm{HCO}_{3}^{-}$and $\mathrm{Cl}^{-}$ions to the IPSC and the lower permeability of $\mathrm{HCO}_{3}^{-}$through the GABA channel. The decay time constant was again reduced, as expected, by low internal $\mathrm{Cl}^{-}$concentrations in normal aCSF (Fig. 4E) (150 mM $\mathrm{Cl}^{-}$, median $=8.9 \mathrm{~ms} ; 10 \mathrm{~mm} \mathrm{Cl}^{-}$median $=6.3 \mathrm{~ms})$. The extent of the reduction in eIPSC decay times by low internal $\mathrm{Cl}^{-}$remained unaffected by the $\mathrm{HCO}_{3}^{-}$free solution $\left(150 \mathrm{mM} \mathrm{Cl}^{-}\right.$, median $=9.5$ $\mathrm{ms} ; 10 \mathrm{mM} \mathrm{Cl}^{-}$median $=6.3 \mathrm{~ms}$ ) (Fig. $4 E$ ), indicating that as a permeant ion, only $\mathrm{Cl}^{-}$are necessary and sufficient to regulate the decay phase of the eIPSC.

\section{Low $\mathrm{Cl}^{-}$regulates IPSC decay times by directly affecting $\mathrm{GABA}_{\mathrm{A}}$ receptor function}

To determine whether the $\mathrm{Cl}^{-}$modulation is intrinsic to the synaptic $\mathrm{GABA}_{\mathrm{A}}$ receptor, rather than mediated by receptorassociated molecules located at inhibitory synapses (Lüscher and Keller, 2004), we expressed $\alpha 1 \beta 2 \gamma 2 \mathrm{~L}$ subunits in human embryonic kidney (HEK) cells. This combination of subunits was chosen to replicate the likely composition of synaptic $\mathrm{GABA}_{\mathrm{A}}$ receptors in Purkinje cells (Laurie et al., 1992; Fritschy and Mohler, 1995). Outside-out patches were briefly exposed to saturating concentrations of GABA $(3 \mathrm{~mm}, 1 \mathrm{~ms})$ to emulate the GABA concentration transient in the synaptic cleft (Jones and Westbrook, 1995). With either $150 \mathrm{~mm}$ (Fig. 5A,B) or $10 \mathrm{~mm}$ (Fig. 5C,D) internal $\mathrm{Cl}^{-}$concentrations, the GABA-activated current $\left(I_{\mathrm{GABA}}\right)$ decays were best fit by two or three exponential components. Over a patch potential range from $-100 \mathrm{mV}$ to +60 $\mathrm{mV}$, the weighted $\tau_{\text {decay }}$ for $I_{\mathrm{GABA}}$ increased monotonically in a similar manner to the decay time constants for evoked and spontaneous IPSCs. The weighted $\tau_{\text {decay }}$ for inward $I_{\mathrm{GABA}}$ at $-100 \mathrm{mV}$ was significantly reduced by $10 \mathrm{~mm}$ intracellular $\mathrm{Cl}^{-}$from $54.5 \pm$ $5.8(n=10)$ to $21.1 \pm 2.9 \mathrm{~ms}(n=10, p=0.0002$, two-tailed $t$ test) (Fig. $5 E$ ). A similar reduction in $\tau_{\text {decay }}$ was observed (from $75.4 \pm 13.6$ to $40.9 \pm 8.3 \mathrm{~ms}, p=0.04$ ) when the same patches were held at $60 \mathrm{mV}$ causing the direction of the GABA-activated currents to become net outward. The consistent effects of internal $\mathrm{Cl}^{-}$concentration on the current decays mediated by both synaptic and recombinant $\mathrm{GABA}_{\mathrm{A}}$ receptors, with their similar subunit composition, strongly indicates that $\mathrm{Cl}^{-}$is modulating the receptor directly, rather than acting via receptor-associated molecules. However, while elements of the postsynaptic density will 
not be present in HEK cells, it is conceivable that some remnants of receptorassociated molecules, such as protein kinases, may be present in outside-out patches and these might be affected by $\mathrm{Cl}^{-}$concentration thereby affecting macroscopic GABA current decays. To address this, we included the broad spectrum serine/threonine kinase inhibitor, staurosporine (500 nM), in the patch pipette and repeated the rapid GABA applications in the presence of low and high $\mathrm{Cl}^{-}$concentrations. The weighted $\tau_{\text {decay }}$ for inward $I_{\mathrm{GABA}}$ at $-100 \mathrm{mV}$ was again significantly reduced by $10 \mathrm{~mm}$ internal $\mathrm{Cl}^{-}$from $45.1 \pm 2.7(n=6)$ to $20.1 \pm 3.3$ ms ( $n=5, p=0.0004$, unpaired $t$ test), yielding a $\tau($ high $\mathrm{Cl}) / \tau($ low $\mathrm{Cl}$ ) ratio of 2.3 , which is very similar to that measured in the absence of staurosporine (2.5). Thus internal $\mathrm{Cl}^{-}$is most likely modulating the receptor by a direct action rather than through receptor-associated signaling molecules.

\section{Implications of fast-decaying IPSCs for synaptic inhibition}

Given that the physiological $\mathrm{Cl}^{-}$concentration in an adult neuron is lower than we routinely use in our symmetrical $\mathrm{Cl}^{-}$ solutions, it is likely that the real profile of an IPSC in an intact cell is much shorter than we previously thought. Therefore, does the speed of the IPSC decay, and the corresponding effect this has on the time window for inhibition, reduce the effectiveness of synaptic inhibition in controlling neuronal excitability? This question was addressed by recording from Purkinje cells under current-clamp conditions and then injecting inhibitory conductances using a dynamic clamp amplifier. We evoked a continuous spike train in the Purkinje cell with a constant current pulse $(\sim 200 \mathrm{pA})$ before introducing an artificial inhibitory conductance to inhibit the train. To reproduce the IPSCs expected in a Purkinje cell with either high $(150 \mathrm{~mm})$ or low $(10 \mathrm{~mm})$ internal $\mathrm{Cl}^{-}$concentrations, the conductance decay time constants were set to 12.5 and $8.5 \mathrm{~ms}$, respectively (Fig. 6A). Action potentials ceased immediately after the onset of the artificial inhibitory conductance, and the latency to the first spike was significantly increased when the injected conductance had a longer decay time (average first latency changed from $41 \pm 2$ to $54 \pm 4 \mathrm{~ms}, n=9$ ) (Fig. $6 A, B$ ).

As an alternative approach to assess the impact of the kinetics of inhibition on cell excitability, we injected a brief excitatory conductance into the soma of the Purkinje cell under current clamp to emulate the activation of synaptic AMPA-type glutamate receptors at climbing fiber excitatory synapses and initiate action potential firing (Traynelis et al., 1993). An inhibitory conductance with either slow or fast kinetics (based on the internal $\mathrm{Cl}^{-}$concentration) was also introduced and its latency varied so that the inhibitory conductance was active over a time window that encompassed the excitation. A slow inhibitory conductance, which preceded an excitatory conductance, inhibited spike firing within a time window of $\sim 37 \mathrm{~ms}$ (Fig. $6 C, D$ ). For the faster inhibitory conductance, typical of neurons exposed to low internal $\mathrm{Cl}^{-}$, this window is significantly reduced by over half to $15 \mathrm{~ms}$.

\section{Discussion}

Internal $\mathrm{Cl}^{-}$regulates IPSC decay by a direct effect on the $\mathrm{GABA}_{\mathrm{A}}$ receptor

We have demonstrated here, for the first time, that the duration of GABAergic synaptic inhibition is strongly influenced by the intracellular concentration of $\mathrm{Cl}^{-}$, the $\mathrm{GABA}_{\mathrm{A}}$ receptor's major permeating anion. Indeed, by studying a range of internal $\mathrm{Cl}^{-}$ concentrations, we observed that the IPSC decay time constant was clearly affected by changes to the $\mathrm{Cl}^{-}$concentration over a range that is considered to be physiologically relevant (e.g., between 5 and $30 \mathrm{~mm}$ ).

It is important to note that $\mathrm{GABA}_{\mathrm{A}}$ receptor channels are also permeable to $\mathrm{HCO}_{3}^{-}$ions (Kaila et al., 1993), and it is conceivable that these might have emulated or supplemented the effect of internal $\mathrm{Cl}^{-}$on the IPSC decay times, by competing with $\mathrm{Cl}^{-}$ ions for the same binding site(s) on the receptor. Under our recording conditions, using aCSF with a partial pressure of $\mathrm{CO}_{2}$ of $\sim 37.5 \mathrm{mmHg}$, the intracellular $\mathrm{HCO}_{3}^{-}$concentration lies between 8 and $13 \mathrm{~mm}$, at an intracellular $\mathrm{pH}$ of 7.2-7.4. This implies 

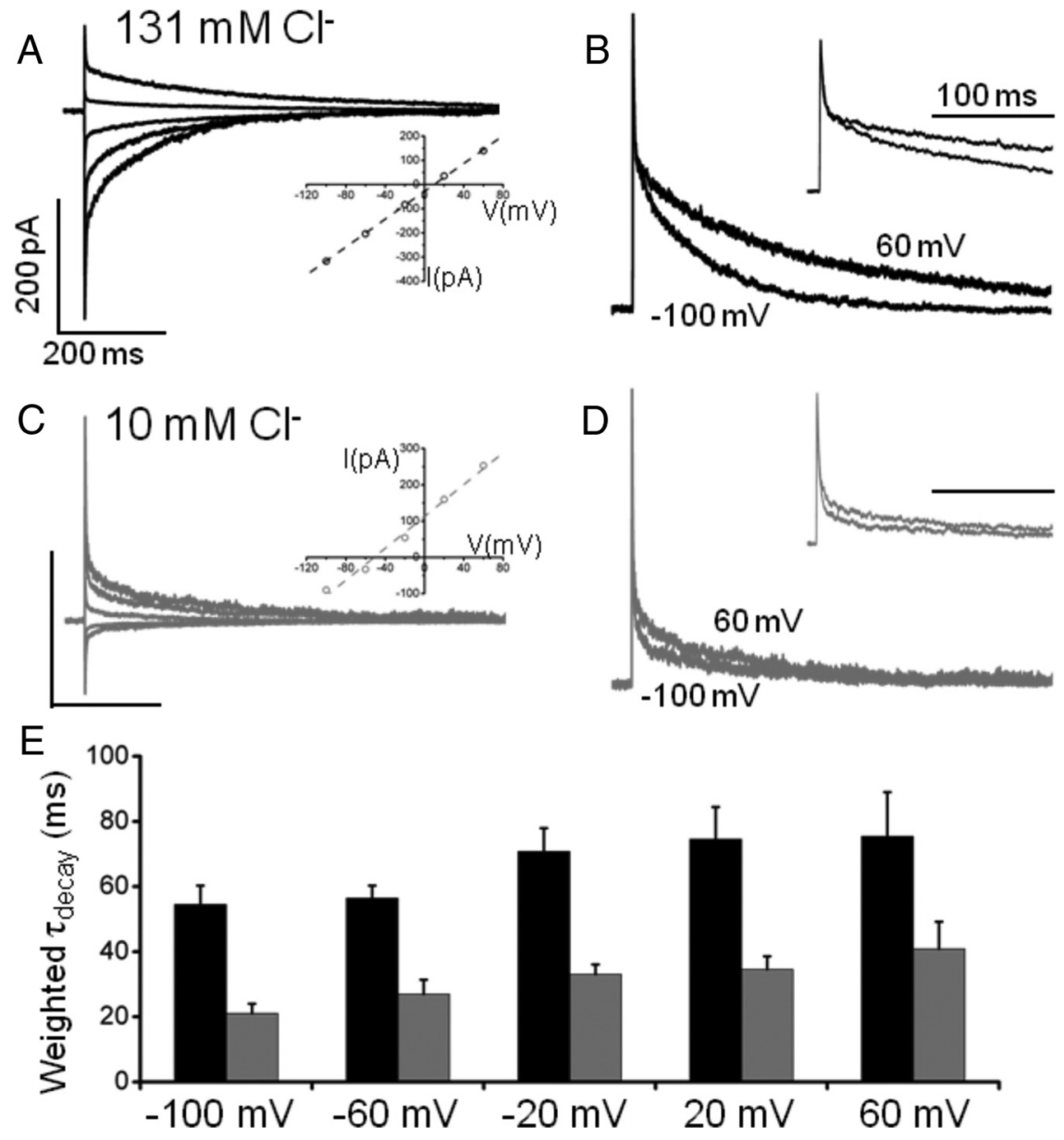

Figure 5. Recombinant $\alpha 1 \beta 2 \gamma 2 \mathrm{LGABA}_{A}$ receptor kinetics are modulated by intracellular $\mathrm{Cl}^{-}$. Shown are currents activated by $3 \mathrm{~mm}$ GABA (1 ms pulse) recorded from outside-out patches of HEK cells expressing GABA $A_{A}$ receptors. $A$, GABA currents recorded at -100 to $60 \mathrm{mV}$ ( $40 \mathrm{mV}$ steps, average of 10 sweeps per voltage) with $150 \mathrm{~mm} \mathrm{Cl}^{-}$in the pipette solution decay more slowly at positive potentials. Inset, $A n I-V$ plot for GABA-activated currents ( $E_{\text {rev }}$ is $7 \mathrm{mV}$ ). $\boldsymbol{B}$, Peak-scaled, superimposed currents at -100 and $60 \mathrm{mV}$. Note the currents recorded at $-100 \mathrm{mV}$ have been flipped to match those at $60 \mathrm{mV}$. C, The same experiment repeated with $10 \mathrm{~mm}$ intracellular $\mathrm{Cl}^{-}$. Currents reverse at $-56 \mathrm{mV}$ (inset). The relative voltage dependence of the weighted decay time constant is maintained (compare peak-scaled currents in $\boldsymbol{D}$ ), but at all membrane voltages, the decay time is $2-3$ times faster in low $\mathrm{Cl}^{-}$(average of 12 sweeps). $\boldsymbol{E}$, Summary of weighted decay times in $150 \mathrm{~mm}$ (black) and $10 \mathrm{~mm}$ (gray) $\mathrm{Cl}^{-}$at all the voltages tested. The calibrations in $\boldsymbol{A}$ and $\boldsymbol{B}$ apply to the bars in $\boldsymbol{C}$ and $\boldsymbol{D}$, respectively.

the equilibrium potential for $\mathrm{HCO}_{3}^{-}$is between -18 and -31 $\mathrm{mV}$. Therefore, the maximum contribution of $\mathrm{HCO}_{3}^{-}$to the eIPSC will occur when we are recording with low internal $\mathrm{Cl}^{-}$at $-100 \mathrm{mV}$. However, even under these conditions, the removal of $\mathrm{HCO}_{3}^{-}$ions did not affect the decay time constant, indicating that $\mathrm{Cl}^{-}$, in the context of permeant ions, is the major determinant of the IPSCs decay kinetics.

A link between the effectiveness of inhibition and internal $\mathrm{Cl}^{-}$has been noted previously from early intracellular current-clamp recordings of CA1 pyramidal neurons using $3 \mathrm{M}$ $\mathrm{KCl}$ and $2 \mathrm{M} \mathrm{KCH}_{3} \mathrm{SO}_{4}$-filled electrodes (Alger and Nicoll, 1979). A prolonged time course of the depolarizing IPSP was observed in neurons where $\mathrm{Cl}^{-}$leakage had occurred from the $\mathrm{KCl}$ pipette. Although the duration of synaptic potentials is also dependent on the membrane time constant, most likely this prolongation reflected the phenomenon of internal $\mathrm{Cl}^{-}$affecting IPSC decays that we report in the present study.

There are several mechanisms by which $\mathrm{Cl}^{-}$could regulate the decay phase kinetics of the IPSC. One possibility is that high internal $\mathrm{Cl}^{-}$prolongs the IPSC decay by slowing the uptake of GABA by the principal neuronal GABA transporter subtype, GAT-1 (Guastella et al., 1990), which is thought to have a stoichiometry of $2 \mathrm{Na}^{+}: 1 \mathrm{GABA}: 1 \mathrm{Cl}^{-}$(Cammack et al., 1994). This is unlikely to account for our findings because GABA current kinetics also became slower with high internal $\mathrm{Cl}^{-}$in excised outside-out patches where GABA is applied by a rapid application system and GABA transport plays no role in the current decay process. This result also indicated that the regulation by internal $\mathrm{Cl}^{-}$must be an intrinsic property of the $\mathrm{GABA}_{\mathrm{A}}$ receptor and does not depend on intracellular signaling mechanisms and on receptor-associated molecules, many of which, such as gephyrin, are not expressed in HEK cells (Thomas and Smart, 2005).

The results obtained with the recombinant $\mathrm{GABA}_{\mathrm{A}}$ receptors suggest that one or more sites must exist on the receptors that are capable of binding $\mathrm{Cl}^{-}$. There appear to be no clear structural consensus sequences for $\mathrm{Cl}^{-}$binding sites (Plested and Mayer, 2007), but as internal $\mathrm{Cl}^{-}$regulates the IPSC decay, such sites are most likely to be found within the intracellular domains between M1 and M2, or between M3 and M4, or conceivably within the ion channel and its associated internal vestibule. Some support for the latter structure as a potential site(s) comes from prior studies of acetylcholine receptors in Aplysia neurons, where the concentration of the permeating ion was directly related to the mean channel open time, and occupancy of such a site(s) in the ion channel was postulated to prolong the channel open duration (Ascher et al., 1978; Marchais and Marty, 1979).

\section{Physiological impact of regulating the speed of} synaptic inhibition

We predict that the regulation of $\mathrm{GABA}_{\mathrm{A}}$ receptor function by internal $\mathrm{Cl}^{-}$is likely to have significant consequences for neuronal excitability, because the duration over which an inhibitory input can effectively counteract coincident neuronal excitation is appreciably shorter with low physiological levels of $\mathrm{Cl}^{-}$compared with that observed with symmetrical high $\mathrm{Cl}^{-}$. This is fundamentally important, as intracellular $\mathrm{Cl}^{-}$concentrations are subject to alteration by the density and activity of $\mathrm{Cl}^{-}$transporters (DeFazio et al., 2000), which will influence IPSC time profiles and thereby signal integration.

Our finding that the kinetics of $\mathrm{GABA}_{\mathrm{A}}$ receptor currents are modulated by internal $\mathrm{Cl}^{-}$ions has many implications for our understanding of synaptic inhibition. It is clear that we have been underestimating the speed of inhibitory transmission. This has occurred because of the routine use of symmetrical $\mathrm{Cl}^{-}$recording solutions to depolarize $E_{\mathrm{Cl}}$ close to $0 \mathrm{mV}$, to ensure that the IPSCs are of large amplitudes for ease of measurement when 


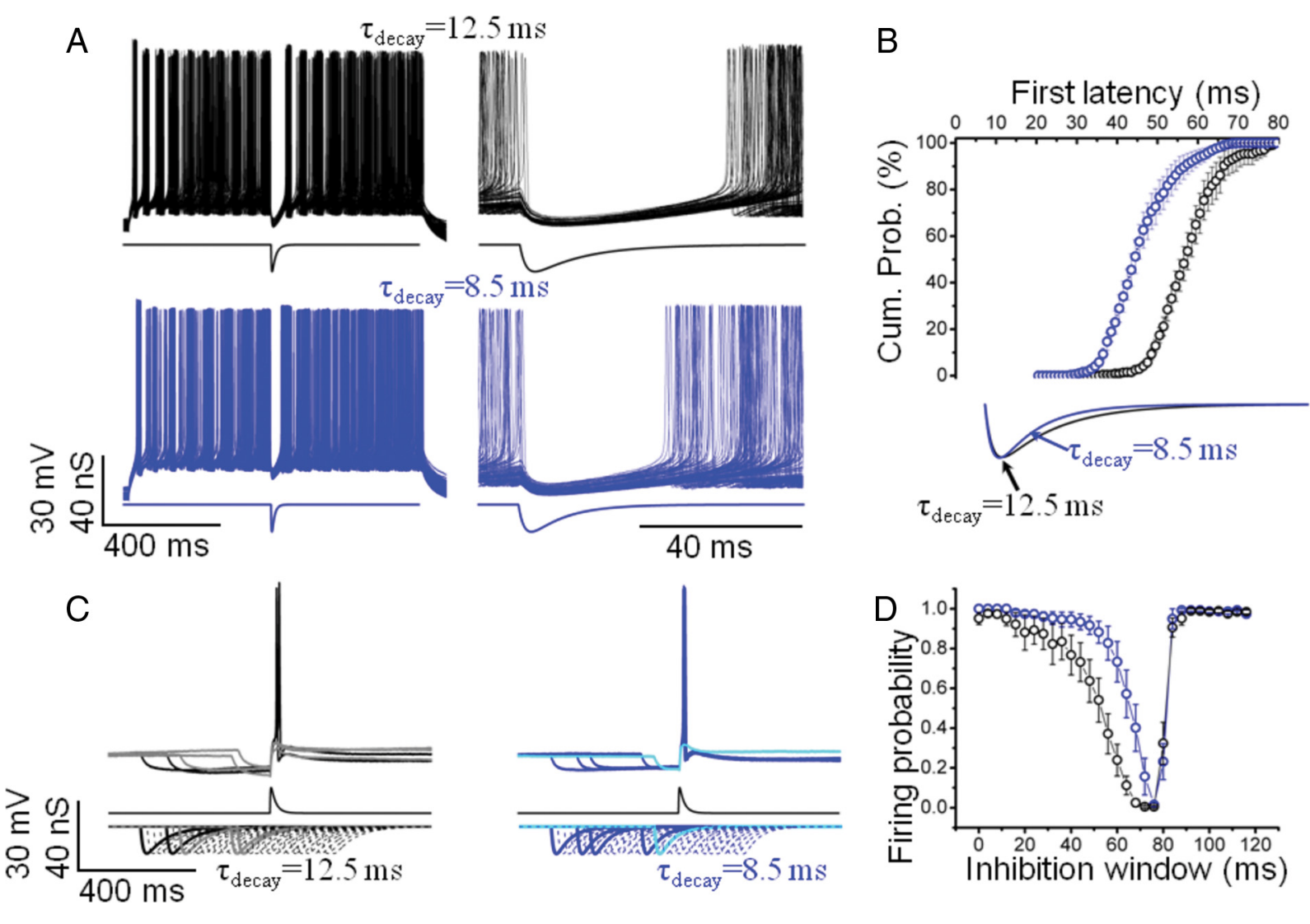

Figure 6. Decay times of inhibitory synaptic conductances profoundly affect Purkinje neuron excitability. $A$, Constant current pulse $(1 \mathrm{~s}, 200 \mathrm{pA})$ evoked spike firing in a Purkinje neuron with slow (12.5 ms decay time, black) and fast ( $8.5 \mathrm{~ms}$ decay time, blue) inhibitory conductances $\left(E_{\text {rev }}=-82 \mathrm{mV}\right)$ (Chavas and Marty, 2003) injected through a conductance clamp amplifier during the train. The fast conductance is reflected by the shorter inhibition time window [see expanded timescale, right panel; 99 (fast conductance) and 102 (slow) overlaid sweeps at $-65 \mathrm{mV}$ ]. B, The cumulative distribution for first spike latencies after conductance injection is significantly displaced to the right for longer-lasting conductances ( $n=9$, time course of the conductance injection is shown below). C, Injecting an excitatory conductance $\left(E_{\text {rev }}=0 \mathrm{mV}, \tau_{\text {rise }}=0.3 \mathrm{~ms}, \tau_{\text {decay }}=3 \mathrm{~ms}\right.$, conductance fixed at $20 \%$ above threshold, typically $\left.12-18 \mathrm{nS}\right)$ to induce a single spike with a concurrent sliding inhibitory conductance (fixed at $15 \mathrm{nS}$ ) with either slow (left, black) or fast (right, blue) kinetics. Sweeps are separated by $4 \mathrm{~ms}$, and those shown in the top panel correspond to conductances depicted as thick lines in the lower panel. The cell is prevented from firing by the inhibition time window, which is reduced from $\sim 50$ to $\sim 20 \mathrm{~ms}$ for the fast conductance injection (measured over $50-60$ trains of injections, alternating between fast and slow conductance injection). $\boldsymbol{D}$, Summary of the duration of the inhibition windows for fast (blue) and slow (black) conductance injections.

holding cells near to their resting membrane potentials. By using physiological concentrations of internal $\mathrm{Cl}^{-}$, the shorter time window now available for synaptic inhibition will reduce its effect on cell excitability with consequences for synaptic plasticity and presumably the modeling of neuronal network behavior. Indeed, at physiological body temperatures, the real durations of IPSCs are so short that they now approach $2-3 \mathrm{~ms}$, and therefore become difficult to resolve accurately with the level of filtering imposed by the recording apparatus.

Furthermore, the kinetics of $I_{\mathrm{GABA}}$ for recombinant $\mathrm{GABA}_{\mathrm{A}}$ $\alpha 1 \beta 2 \gamma 2 \mathrm{~L}$ receptors expressed in HEK cells exhibited a similar sensitivity to the internal $\mathrm{Cl}^{-}$concentration. This combination of $\mathrm{GABA}_{\mathrm{A}}$ receptor subunits is considered to account for at least $30 \%$ of inhibitory synaptic $\mathrm{GABA}_{\mathrm{A}}$ receptors in the CNS (Whiting et al., 1995), indicating that their regulation by internal $\mathrm{Cl}^{-}$, may well be a universal feature of many inhibitory synapses across the CNS. Indeed, a similar phenomenon is also apparent for the glycine receptor (Pitt et al., 2008), indicating that regulation by internal $\mathrm{Cl}^{-}$may be an intrinsic property of all ligandgated anion channels in the Cys-loop superfamily.

The regulation of the speed of IPSC decays may also be relevant to neurons during postnatal development. The higher internal $\mathrm{Cl}^{-}$concentrations that characterize this stage of neurodevelopment (Ben-Ari et al., 2007) would allow $\mathrm{GABA}_{\mathrm{A}}$ receptor activation to initiate more prolonged depolarization, eventually exceeding the threshold for voltage-gated calcium channel activation (Cherubini et al., 1991). Even for more mature neurons with lower basal $\mathrm{Cl}^{-}$concentrations, the prolonged activation of $\mathrm{GABA}_{\mathrm{A}}$ receptors in structurally small dendrites can eventually lead to $\mathrm{Cl}^{-}$loading and membrane depolarization, which is exacerbated by $\mathrm{HCO}_{3}^{-}$efflux (Staley and Proctor, 1999). Under these conditions, the time course of the synaptic GABA currents would again be prolonged with consequences for neuronal excitability.

It has also been reported that $E_{\mathrm{Cl}}$ can vary between the dendrites and the soma, affecting synaptic inhibition in the same neuron (Duebel et al., 2006; cf. Glickfeld et al., 2009). We would predict that the time course of, and therefore the time window for, synaptic inhibition will be shorter, where the $\mathrm{Cl}^{-}$concentration is lowest and thus IPSCs with dendritic and somatic origins could have different time courses in the same cell. This newly discovered role for $\mathrm{Cl}^{-}$will have important implications not only for how synaptic inhibition regulates the activity of neuronal networks, but also for understanding how alterations in internal $\mathrm{Cl}^{-}$affect early neuronal development (Ben-Ari, 2002) and the progression of pathophysiological conditions, such as epilepsy (Huberfeld et al., 2007) and chronic pain (Coull et al., 2003).

\section{References}

Alger BE, Nicoll RA (1979) GABA-mediated biphasic inhibitory responses in hippocampus. Nature 281:315-317. 
Ango F, di Cristo G, Higashiyama H, Bennett V, Wu P, Huang ZJ (2004) Ankyrin-based subcellular gradient of neurofascin, an immunoglobulin family protein, directs GABAergic innervation at Purkinje axon initial segment. Cell 119:257-272.

Ascher P, Marty A, Neild TO (1978) Life time and elementary conductance of the channels mediating the excitatory effects of acetylcholine in Aplysia neurones. J Physiol 278:177-206.

Barberis A, Mozrzymas JW, Ortinski PI, Vicini S (2007) Desensitization and binding properties determine distinct $\alpha 1 \beta 2 \gamma 2$ and $\alpha 3 \beta 2 \gamma 2$ GABAA receptor-channel kinetic behavior. Eur J Neurosci 25:2726-2740.

Ben-Ari Y (2002) Excitatory actions of GABA during development: the nature of the nurture. Nat Rev Neurosci 3:728-739.

Ben-Ari Y, Gaiarsa JL, Tyzio R, Khazipov R (2007) GABA: a pioneer transmitter that excites immature neurons and generates primitive oscillations. Physiol Rev 87:1215-1284.

Bormann J, Hamill OP, Sakmann B (1987) Mechanism of anion permeation through channels gated by glycine and $\gamma$-aminobutyric acid in mouse cultured spinal neurones. J Physiol 385:243-286.

Bright DP, Aller MI, Brickley SG (2007) Synaptic release generates a tonic $\mathrm{GABA}_{\mathrm{A}}$ receptor-mediated conductance that modulates burst precision in thalamic relay neurons. J Neurosci 27:2560-2569.

Cammack JN, Rakhilin SV, Schwartz EA (1994) A GABA transporter operates asymmetrically and with variable stoichiometry. Neuron 13:949-960.

Chavas J, Marty A (2003) Coexistence of excitatory and inhibitory GABA synapses in the cerebellar interneuron network. J Neurosci 23:2019-2031.

Cherubini E, Gaiarsa JL, Ben-Ari Y (1991) GABA: an excitatory transmitter in early postnatal life. Trends Neurosci 14:515-519.

Collingridge GL, Gage PW, Robertson B (1984) Inhibitory post-synaptic currents in rat hippocampal CA1 neurones. J Physiol 356:551-564.

Coull JA, Boudreau D, Bachand K, Prescott SA, Nault F, Sík A, De Koninck P, De Koninck Y (2003) Trans-synaptic shift in anion gradient in spinal lamina I neurons as a mechanism of neuropathic pain. Nature 424: 938-942.

DeFazio RA, Keros S, Quick MW, Hablitz JJ (2000) Potassium-coupled chloride cotransport controls intracellular chloride in rat neocortical pyramidal neurons. J Neurosci 20:8069-8076.

Duebel J, Haverkamp S, Schleich W, Feng G, Augustine GJ, Kuner T, Euler T (2006) Two-photon imaging reveals somatodendritic chloride gradient in retinal ON-type bipolar cells expressing the biosensor Clomeleon. Neuron 49:81-94.

Duguid IC, Smart TG (2004) Retrograde activation of presynaptic NMDA receptors enhances GABA release at cerebellar interneuron-Purkinje cell synapses. Nat Neurosci 7:525-533.

Fritschy J-M, Mohler H (1995) GABA $_{\mathrm{A}}$ receptor heterogeneity in the adult rat brain: differential regional and cellular distribution of seven major subunits. J Comp Neurol 359:154-194.

Glickfeld LL, Roberts JD, Somogyi P, Scanziani M (2009) Interneurons hyperpolarize pyramidal cells along their entire somatodendritic axis. Nat Neurosci 12:21-23.

Guastella J, Nelson N, Nelson H, Czyzyk L, Keynan S, Miedel MC, Davidson N, Lester HA, Kanner BI (1990) Cloning and expression of a rat brain GABA transporter. Science 249:1303-1306.

Hefft S, Jonas P (2005) Asynchronous GABA release generates long-lasting inhibition at a hippocampal interneuron-principal neuron synapse. Nat Neurosci 8:1319-1328.

Houston CM, Hosie AM, Smart TG (2008) Distinct regulation of $\beta 2$ and $\beta 3$ subunit-containing cerebellar synaptic $\mathrm{GABA}_{\mathrm{A}}$ receptors by calcium/ calmodulin-dependent protein kinase II. J Neurosci 28:7574-7584.

Huberfeld G, Wittner L, Clemenceau S, Baulac M, Kaila K, Miles R, Rivera C (2007) Perturbed chloride homeostasis and GABAergic signaling in human temporal lobe epilepsy. J Neurosci 27:9866-9873.

Jones MV, Westbrook GL (1995) Desensitized states prolong GABA $_{\mathrm{A}}$ channel responses to brief agonist pulses. Neuron 15:181-191.
Jones MV, Westbrook GL (1997) Shaping of IPSCs by endogenous calcineurin activity. J Neurosci 17:7626-7633.

Kaila K (1994) Ionic basis of $\mathrm{GABA}_{\mathrm{A}}$ receptor channel function in the nervous system. Prog Neurobiol 42:489-537.

Kaila K, Voipio J, Paalasmaa P, Pasternack M, Deisz RA (1993) The role of bicarbonate in $\mathrm{GABA}_{\mathrm{A}}$ receptor-mediated IPSPs of rat neocortical neurones. J Physiol 464:273-289.

Kaila K, Lamsa K, Smirnov S, Taira T, Voipio J (1997) Long-lasting GABAmediated depolarization evoked by high-frequency stimulation in pyramidal neurons of rat hippocampal slice is attributable to a network-driven, bicarbonate-dependent $\mathrm{K}^{+}$transient. J Neurosci 17:7662-7672.

Keros S, Hablitz JJ (2005) Subtype-specific GABA transporter antagonists synergistically modulate phasic and tonic $\mathrm{GABA}_{\mathrm{A}}$ conductances in rat neocortex. J Neurophysiol 94:2073-2085.

Laurie DJ, Wisden W, Seeburg PH (1992) The distribution of thirteen $\mathrm{GABA}_{\mathrm{A}}$ receptor subunit mRNAs in the rat brain. III. Embryonic and postnatal development. J Neurosci 12:4151-4172.

Llano I, González J, Caputo C, Lai FA, Blayney LM, Tan YP, Marty A (2000) Presynaptic calcium stores underlie large-amplitude miniature IPSCs and spontaneous calcium transients. Nat Neurosci 3:1256-1265.

Lüscher B, Keller CA (2004) Regulation of GABAA receptor trafficking, channel activity, and functional plasticity of inhibitory synapses. Pharmacol Ther 102:195-221.

Marchais D, Marty A (1979) Interaction of permeant ions with channels activated by acetylcholine in Aplysia neurones. J Physiol 297:9-45.

Mittmann W, Häusser M (2007) Linking synaptic plasticity and spike output at excitatory and inhibitory synapses onto cerebellar Purkinje cells. J Neurosci 27:5559-5570.

Onodera K, Takeuchi A (1979) An analysis of the inhibitory post-synaptic current in the voltage-clamped crayfish muscle. J Physiol 286:265-282.

Otis TS, Mody I (1992) Modulation of decay kinetics and frequency of $\mathrm{GABA}_{\mathrm{A}}$ receptor-mediated spontaneous inhibitory postsynaptic currents in hippocampal neurons. Neuroscience 49:13-32.

Overstreet LS, Westbrook GL (2003) Synapse density regulates independence at unitary inhibitory synapses. J Neurosci 23:2618-2626.

Pitt SJ, Sivilotti LG, Beato M (2008) High intracellular chloride slows the decay of glycinergic currents. J Neurosci 28:11454-11467.

Plested AJR, Mayer ML (2007) Structure and mechanism of kainate receptor modulation by anions. Neuron 53:829-841.

Puia G, Costa E, Vicini S (1994) Functional diversity of GABA-activated $\mathrm{Cl}^{-}$currents in Purkinje versus granule neurons in rat cerebellar slices. Neuron 12:117-126.

Schneggenburger R, Ascher P (1997) Coupling of permeation and gating in an NMDA-channel pore mutant. Neuron 18:167-177.

Staley KJ, Proctor WR (1999) Modulation of mammalian dendritic $\mathrm{GABA}_{\mathrm{A}}$ receptor function by the kinetics of $\mathrm{Cl}^{-}$and $\mathrm{HCO}_{3}^{-}$transport. J Physiol 519:693-712.

Stanfield PR, Ashcroft FM, Plant TD (1981) Gating of a muscle K+ channel and its dependence on the permeating ion species. Nature 289:509-511.

Swenson RP Jr, Armstrong CM (1981) K+ channels close more slowly in the presence of external $\mathrm{K}+$ and $\mathrm{Rb}+$. Nature 291:427-429.

Thomas P, Smart TG (2005) HEK293 cell line: a vehicle for the expression of recombinant proteins. J Pharmacol Toxicol Methods 51:187-200.

Traynelis SF, Silver RA, Cull-Candy SG (1993) Estimated conductance of glutamate receptor channels activated during EPSCs at the cerebellar mossy fiber-granule cell synapse. Neuron 11:279-289.

Wei W, Zhang N, Peng Z, Houser CR, Mody I (2003) Perisynaptic localization of delta subunit-containing $\mathrm{GABA}_{\mathrm{A}}$ receptors and their activation by GABA spillover in the mouse dentate gyrus. J Neurosci 23:10650-10661.

Whiting PJ, McKernan RM, Wafford KA (1995) Structure and pharmacology of vertebrate $\mathrm{GABA}_{\mathrm{A}}$ receptor subtypes. Int Rev Neurobiol 38:95138. 